\title{
Riverine Flood Hazard: Part B. Disaster Risk Reduction in India
}

ROBERT JAMES WASSON ${ }^{1}$, VIKRANT JAIN ${ }^{2,}$, , AJAY KATURI ${ }^{3}$, SIDDHARTHA LAHIRI ${ }^{4}$, SURYA PARKASH $^{5}$, ASHOK KUMAR SINGHVI ${ }^{6}$, NAVARUN VARMA ${ }^{7}$, PRIYA BANSAL ${ }^{1}$ and C. JOON CHUAH ${ }^{1,8}$

${ }^{1}$ Institute of Water Policy, Lee Kuan Yew School of Public Policy, 469A Bukit Timah Road, Singapore 259770

${ }^{2}$ Discipline of Earth Sciences, Indian Institute of Technology Gandhinagar, Palaj, Gandhinagar, Gujarat 382355 , India

${ }^{3}$ Consultant, 61-8/3-5 Kotinagar, Krishnalanka, Vijayawada, Andhra Pradesh 520 013, India

${ }^{4}$ Department of Applied Geology, Dibrugarh University, Dibrugarh 786 004, India

${ }^{5}$ National Institute of Disaster Management, A Wing, $4^{\text {th }}$ Floor, NDCC-II Building, Jai Singh Road, New Delhi 110 001, India

${ }^{6}$ Physical Research Laboratory, Navrangpura, Ahmedabad 380 009, India

${ }^{7}$ Residential College 4 (University Town), National University of Singapore, 6 College Avenue East \#B101, Singapore 138614

${ }^{8}$ Nanyang Environment and Water Research Institute, Nanyang Technological University, 1 Cleantech Loop, Singapore 637141

(Received on 27 March 2018; Revised on 25 July 2018; Accepted on 10 August 2018)

\begin{abstract}
The economic risk from and social vulnerability to riverine floods in India is one of the highest, if not the highest, in the world, with millions of people exposed and vulnerable, and billions of rupees worth of property and infrastructure at risk. Between 1953 and 2011, the total number of human lives lost to floods was 97,551 and the total economic cost of floods in India was 4.506 $\times 10^{12} \mathrm{INR}\left(6912 \times 10^{7}\right.$ USD) in 2017 prices. Embankments have been the dominant flood protection scheme, or Disaster Risk Reduction strategy, since Independence and despite the heroic construction of tens of thousands of embankments to protect lives and property from floods, economic damage continues to rise, even when normalized for inflation to take account of increasing wealth and therefore an increase in the amount of property that can be damaged. Explanations of this apparent paradox vary, but appear to centre on breaches in embankments, incomplete embankments, sedimentation in channels because of embankments and therefore deeper and more dangerous floods, human encroachment onto floodplains partly as a result of 'the levee effect' whereby people feel safe in the presence of embankments, and the displacement of traditional coping mechanisms by government initiatives. While governments, NGOs, and academics have often discussed non-structural DRR, and some is in place, there has been little development of this approach to more completely complement structural interventions to reduce deaths and damage. A workshop of flood management practitioners and analysts in February 2017 produced a set of recommendations for a more robust form of DRR for India, and they are presented as a contribution to at least moderate what has become an existential crisis for many Indians.
\end{abstract}

Keywords: Flood Hazard; Risk; Monsoon Season; Mitigation Policies

\section{Introduction}

The writing of this paper coincided with the 2017 Southwest Monsoon season in India, the horrors of which can be seen in the world's media. Deaths and damage have occurred in Assam, Arunachal Pradesh, Bihar, Gujarat, Maharashtra, Odisha, Chattisgarh, and Andhra Pradesh. While the numbers are uncertain it appears that India-wide more than 600 people have

*Authorfor Correspondence: E-mail: vjain@iitgn.ac.in 
Robert James Wasson et al.

died, and 32.1 million people have been affected, many having to leave their homes to find shelter (The Guardian, $31^{\text {st }}$ July, 2017; Firstpost, $1^{\text {st }}$ August, 2017; UN News Centre, 2017). By 24th August about 341 deaths had occurred and 14.6 million people affected in Bihar, 82 deaths and 1.4 million people affected in Uttar Pradesh, and 152 deaths and 15 million people affected in West Bengal (UN News Centre, 2017). By $6^{\text {th }}$ September 2017, 158 flood-related deaths had been reported in Assam, according to the Water Resources Minister in the Assam Assembly, which is $151 \%$ higher than the average flood season total since 2001. Twelve Districts have been severely impacted, 261 relief camps established, and 1.1 million people affected in Assam. And none of these figures take account of the psychological toll or the deaths that will occur from disease once the floodwaters have receded but stagnant water has not.

The impacts in 2017 appear to have been particularly severe but it will be some time before the economic damage is assessed. This paper, therefore, will appear at an appropriate time to add to the many voices calling for a reassessment of current Indian flood mitigation policies.

\section{Floods in India}

India is home to some of the world's largest rivers, particularly the Ganga and Brahmaputra, which produce riverine floods of prodigious size. Most flooding occurs in the Ganga-Brahmaputra catchments, and there can be severe flooding in Gujarat, Odisha, Punjab, Haryana, West Bengal, Maharashtra, and Andhra Pradesh (Kapur, 2010; Singh and Kumar, 2013).

The Brahmaputra at Bahadurabad, just over the Indian border in Bangladesh, has a mean annual peak discharge of $67,000 \mathrm{~m}^{3} \mathrm{sec}^{-1}$, while at Hardinge Bridge the Ganga produces a mean of $54,000 \mathrm{~m}^{3}$ $\mathrm{sec}^{-1}$ (Mirza, 2002). Rakhecha (2002) has shown that most of the largest Indian floods of the past 100 years are comparable with the largest floods worldwide, and two were world record-breaking events. From data on fatal floods published by the India Meteorological Department, Singh and Kumar (2013) report a rising incidence of flood events between 1978 and 2006 but combine in their explanation climate, awareness and reporting frequency without distinguishing between these causes. For a detailed account of Indian floods, their analysis and causes, see Part A.

\section{Flood Impacts: People and Property Impacted and at Risk}

Average annual impact figures from the Central Water Commission (CWC, 2005; accessed on 13/10/17) and National Disaster Management Authority (2008) between 1953 and 2005 are as follows: the area affected by floods in India was 75.5 lakh ha $\left(74.1 .10^{5}\right.$ ha), of which 35.1 lakh ha of cropped land was affected; 3.28 crore $\left(3.28 .10^{7}\right)$ people were affected; 12.2 lakh houses were damaged; 1587 human lives were lost; and 95,000 head of cattle were lost. From a slightly longer data series from the same sources for 1953 to 2011, the total number of human lives lost to floods was 97,551 and the total economic damage from floods in India was 4.506.10 12 INR $\left(6,912.10^{7}\right.$ USD) corrected for inflation to 2017 prices.

These data are collected at the village level, then aggregated at the Block, District and State levels, and collated by the Central Water Commission. They are, however, of unknown accuracy and precision, but they are the only observations available and have been coupled with meteorological and hydrological data by the India Meteorological Department (e.g. 2010) for analysis. The CWC data appear to have been collected in the same way from the beginning of the record and therefore, do not suffer from increased reporting and are, therefore, comparable through time (see McDermott et al., 2014 for an analysis of the problem of systematically collecting such data). The NDMA (2008) called for a more rigorous method for collecting these data, a recommendation that appears to have received no attention.

While the average figures of deaths and economic damage are useful, it is also important to know if there are trends through time. For the period from 1953 to 2011 the data for annual deaths have been normalized by dividing by the total Indian population to remove the effect of population increase, and total economic damage has been normalized to the year 2017 by using the 2016-2017 Gross National Product (GNP) deflator to remove the effect of growing wealth and therefore the increasing potential for more damage. The time series were tested for trends using the non-parametric Mann-Kendall Tau (b) statistic. 
Normalized economic damage increased from 1953 to $2011(\mathrm{p}<0.01)$ and showed no trend between 1982 and 2011. But this simple trend analysis is insufficient to capture the dynamics of damages. The normalized damage data show an increase from 1953 to a peak in 1985 , then a decline to about 1995 , then a rise to 2010 (Fig. 1). The cause(s) of these variations are not clear, but possibilities will be considered below. Flood-related normalized deaths increased from 1953 to $1981(\mathrm{p}<0.01)$ but then declined to 2011 from 1982 $(\mathrm{p}<0.01)$.

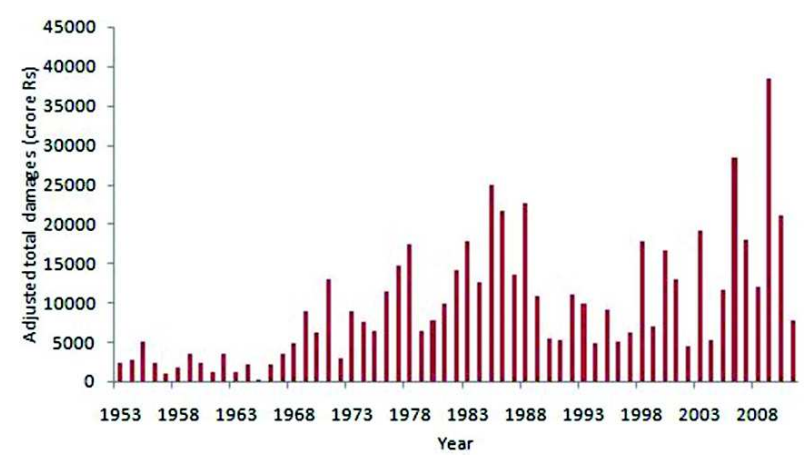

Fig. 1: Normalized All-India economic damage from floods, 1953-2011. Data from the CWC

Further, trends of flood damage data in different states were analysed using the same method (Table 1). Orissa and Andhra Pradesh show statistically significant positive (increasing) trends in flood damage with respect to time, while Haryana, Punjab, Rajasthan, Madhya Pradesh and Maharashtra show statistically significant negative (decreasing) trends in flood damage.

Because the CWC data are of uncertain accuracy and precision, other estimates of impact are needed. Winsemius et al. (2015) and the World Resources Institute (2015) used a global tool called Aqueduct Global Flood Analyzer (AGFA, 2017) to provide estimates both for the present and future. The AGFA includes a hydrologic model, climate change scenarios, future socio-economic scenarios, and a range of flood protection standards (FPS) (Ward et al., 2013). The results from the modelling are extremely sensitive to the FPS and the adopted future climate scenarios.

According to this analysis there are 4.48 million people at risk from riverine floods in India, ranking India number one in the world for the number of people
Table 1: Trends in adjusted damages in different states of India. Trends in adjusted damages over time (1953-2011), y $=$ Adjusted damages, $x=$ Time period

\begin{tabular}{lccc}
\hline States & Kendall's tau-b & p-value & n (sample size) \\
\hline Bihar & 0.007 & 0.9427 & 59 \\
Odisha & 0.2148 & $0.0185^{* *}$ & 59 \\
Andhra Pradesh & 0.2439 & $0.0076^{*}$ & 59 \\
Gujarat & -0.0195 & 0.8339 & 59 \\
Haryana & -0.2719 & $0.0033^{*}$ & 59 \\
Punjab & -0.3099 & $0.0007^{*}$ & 59 \\
Rajasthan & -0.3386 & $0.0017^{*}$ & 43 \\
UP & -0.0195 & 0.8339 & 59 \\
West Bengal & 0.0721 & 0.4248 & 59 \\
MP & -0.2590 & $0.0401^{* *}$ & 33 \\
Chhattisgarh & -0.0747 & 0.5374 & 36 \\
Kerala & -0.0884 & 0.4062 & 44 \\
Maharashtra & -0.3048 & $0.0061^{*}$ & 41 \\
Uttarakhand & -0.1815 & 0.0507 & 58 \\
\hline
\end{tabular}

Note : $*$ denotes significance at $1 \%$ level $; * *$ denotes the same at $5 \%$ level

exposed. The second most exposed country is Bangladesh with 3.48 million people at risk, and at number three is China with 3.28 million people at risk. India also has the most GDP at risk from floods, at USD 14.3 billion (about $15 \%$ of the global total at risk), followed by Bangladesh at USD 5.4 billion.

Scussolini et al. (2016) include three components in FPS: a design component that includes actual FPS such as levees, water retention areas and reservoirs; a policy component that includes regulations, although they recognize that there is no certainty about conformity to the regulations; and a model component that aims to estimate a protection standard for each country based on assumed standards ( 2 to 1000 year return periods), national wealth (assuming that this to some degree determines the FPS), and an estimate of the expected annual damages based on the estimated FPS. But Winsemius et al. (2015) did not incorporate all of these components. Rather they used the assumptions of 'no FPS' and 'Partial FPS' where protection against floods with return periods of 100years is assumed for high income countries and 5year return periods for low income countries.

The AGFA provides estimates of urban damage from floods for different levels of FPS in 2010 and 
for 2030; that is, it uses a base protection level that can be adjusted by the user. According to the manual of the Flood Management Organization (2012), embankments for townships and industrial areas in India should be designed to withstand the 100-year flood (i.e. the flood with a 100-year return period or an annual probability of 0.01 ), and for agricultural areas the 25-year flood should be the design flood or the 50-year flood when anti bank erosion measures are included. Maximum observed floods may also be used to design an embankment crest level. Also a benefit : cost ratio $>1$ is applied but it is not clear if the design flood or the cost benefit ratio takes precedence. Nor is it clear if the disadvantagess of embankments, such as water logging and resulting crop losses, are included in either the recommended or calculated benefit : cost ratios (cf. Kull et al., 2008). Therefore, the AGFA has been used to produce the data in Table 2 for different FPS for 2010 and 2030, without taking account of cost benefit ratios.

There are many uncertainties in these estimates, including a maximum relative error of $-50 \%$ to $>50 \%$ between modelled and observed discharges with a 10-year return period (Ward et al., 2013) to which should be added an assumed $30 \%$ error in measured flood volumes (A.D. Ziegler, pers. comm, 2017) which, in quadrature, gives a maximum total error of $> \pm 58 \%$. The estimated future changes to urban areas and populations, urban flood risk from climate change, and the nature of precipitation changes are all prone to errors that are largely unquantifiable. Therefore, the total relative error is likely to be much greater than $\pm 58 \%$ thereby raising questions about the value of the estimates of damage from AGFA. But the AGFA is the only available comprehensive framework for such estimates.

The CWC data show for the base year of 2010 (used in the AGFA) that there were $18.3 \times 10^{6}$ people affected by floods in India. Ignoring uncertainties, the difference by a factor of about four between the CWC and AGFA estimates is because AGFA calculates atrisk urban populations, while the CWC data include both urban and rural populations. According to the Census of India 2011 India's urban population was $31 \%$ of the total, although the definition of urban areas in India is complicated by large and densely populated villages on the Ganga Plain in particular that are not included in the urban category. The Census figures,
CWC figures and the results from AGFA suggest that floods affect about $1.2 \%$ of the urban population and about $1.7 \%$ of the rural population.

India has the most people exposed to floods globally according to AGFA, and a global analysis by Ward and Shively (2017) shows that India has the highest social vulnerability to floods. Their analysis is for the period from 1980 to 2007 and includes data on deaths and the numbers of people affected, but not economic damages because of the unreliability of global data, along with proxy variables for social and institutional vulnerability. The proxy variables are per capita income, the total relative size of marginalized ethnic groups, the Gini coefficient as a descriptor of access to resources and economic capital, a measure of economic openness to control for economic ideologies, an institutional quality index (to control for freedom of expression, accountability, political stability, government effectiveness, regulatory quality, rule of law, control of corruption, and absence of violence), and topographic variables accounting for hazard exposure.

The costs of floods in India documented above do not include the expense of flood mitigation schemes, flood relief payments to households, costs to the economy of traumatized people, and evacuation and relief costs. Only some of these costs are readily available, but they appear to be much higher than the economic costs recorded by the CWC. For the years 2007 to 2011 the total economic cost from CWC data was 76109.11 crore INR (at 2017 prices) and the Union Government allocated 7739.72 crore INR for 420 flood mitigation schemes India-wide, of which only 3566.01 crore INR had been allocated because of delays in expenditure and other factors (Comptroller and Auditor General of India, 2017). Under the then prevailing cost sharing scheme, the states were to provide $25 \%$ of the total cost bringing the total to be expended to 19027.27 crore INR. When added to the total economic costs the total increases to 95136.38 crore INR (at 2017 prices), which as noted above is still below the actual cost. The National Calamity Contingency Fund allocated a total of 12,450.3 crore INR between 2000 and 2007 (15923.21 crore INR in 2017 prices) for all disaster types (http:/ /doe.gov.in/national-calamity-contigency-fund-nccf; accessed 19/10/17), most of which was probably spent on flood relief. Also, the Prime Minister's National 
Relief Fund allocated to the States 28,246,000 USD over the period 2011-2014 for victims of floods and heavy rains (http://www.mea.gov.in/prime-ministersnational-relief-fund.htm; accessed 1/2/18). The costs of compensation for land lost for embankment construction does not appear to be available. There is a need to assemble all of the flood-related costs to the people of India so that the impact of floods on the economy can be accurately gauged.

There are many problems with the data and analyses summarized above but it is clear that, whatever India's world ranking, the people of India are seriously exposed to riverine floods and the social vulnerability of the country is very high. It is therefore a matter of urgency to assess the effectiveness of existing flood mitigation measures and seek improvements.

\section{Flood Mitigation and its Limitations}

Many flood mitigation measures are employed in India, including warnings, refuges, relief camps, evacuation, relief payments, and dredging and deepening of channels. Among the FPSs in India embankments are the most common (Gupta et al., 2003). From Table 2 it is noteworthy that if, for example, the FPS was increased from the 2-year design flood (effectively no FPS) to the 500-year flood, the design flood recommended by the Flood Management Organization (2012) for towns and industrial areas, the expected urban damage (indexed to 2010) would decrease by $98 \%$. And for the annual expected urban damage in 2030 the decrease would be $48 \%$, the lower value being a result of climate change. Unfortunately there does not appear to be a register of FPSs for India from which more realistic inputs to AGFA can be made. Also, the design floods take no account of the likelihood that embankments will increase the height of a flood because of reduction in the width of the floodplain, and the effect of spurs that protrude into the river from embankments that slow the flow and increase its height (Sanyal, 2017).

Some of the supporting literature for AGFA mentions both the failure of embankments and also the levee (embankment) effect, but these phenomena are not included in AGFA. In India embankment failures are of considerable importance, and the levee effect may also be important. The Flood Management Organization (2012) notes that the 1980 report by the Rashtriya Barh Ayog (RBA, National Flood Commission) found that 40 million hectares of land are flood-prone (although this value has fluctuated between 14.6 and $175 \times 10^{5}$ ha between 1953 and 2005; National Disaster Management Authority, 2008) of which 10 million hectares are protected by embankments and other engineering works, but that 4 million hectares of the protected land, or $40 \%$, is now flood-prone because of the failure of protection works. While there are many examples in India of embankment failure, perhaps the most spectacular is on the Brahmaputra River where in 2004 fully 50\% failed (Phukan et al., 2012). Embankments close to the river are prone to erosion as the river widens, by overtopping when the river rises, and to failure from structural collapse of the earth used for their construction through piping and seepage. Embankments set well back from the river can also fail by erosion, if there is sufficient overbank flood flow onto the floodplain, or by structural collapse. Some of the reasons for failure in Bihar are provided by Srivastava et al., (2013), including building embankments with slopes that are too steep, allowing deep ruts to form in embankments, permitting trees to be grown on embankments, absence of riprap on embankment faces, a non-standardized inspection check list, and lack of geotechnical expertise.

While in the paper by Srivastava et al. (2013) best practice is inferred to reside in the US Corp of

Table 2: Costs and avoided damages (USD) for different FPSs and climate change scenario C (pessimistic) using AGFA

\begin{tabular}{lccccc}
\hline FPS & $2 \mathrm{yr}$ & $10 \mathrm{yr}$ & $50 \mathrm{yr}$ & $100 \mathrm{yr}$ & $500 \mathrm{yr}$ \\
\hline Annual expected urban damage-2010 & $13.4 \mathrm{~B}$ & $6.4 \mathrm{~B}$ & $1.9 \mathrm{~B}$ & $1.1 \mathrm{~B}$ & $256.4 \mathrm{M}$ \\
Annual avoided urban damage-2010 & 0 & $7.1 \mathrm{~B}$ & $11.5 \mathrm{~B}$ & $12.4 \mathrm{~B}$ & $13.2 \mathrm{~B}$ \\
Increased impact due to socio-economic change-2030 & $89.4 \mathrm{~B}$ & $58.7 \mathrm{~B}$ & $20.8 \mathrm{~B}$ & $12.0 \mathrm{~B}$ & $3.3 \mathrm{~B}$ \\
Increased impact due to climate change-2030 & $31.7 \mathrm{~B}$ & $31.4 \mathrm{~B}$ & $14.7 \mathrm{~B}$ & $9.0 \mathrm{~B}$ & $3.4 \mathrm{~B}$ \\
Annual expected urban damage-2030 & $134.6 \mathrm{~B}$ & $96.4 \mathrm{~B}$ & $37.4 \mathrm{~B}$ & $22.1 \mathrm{~B}$ & $7.0 \mathrm{~B}$ \\
\hline
\end{tabular}


Engineers, Tobin (1995) shows that embankments in the USA fail at an alarming rate but they also prevent some damage. Florsheim and Dettinger (2007) found that levee breaks are governed by climate state and have occurred in $25 \%$ of years during the 20th century on the Sacramento-San Jaoaquin river system in California. In addition, embankments on the Mississippi River have increased the height of floods by $2-4 \mathrm{~m}$ over the past century (Criss and Shock, 2001), that increasing the height of embankments to counter problems in one area can increase flood flows downstream thereby causing failure (Di Baldassarre et al., 2009), and ad hoc variations of embankment heights, perhaps because of local interests and pressure, leads to varying water heights on either riverbank or on the same bank thereby creating complex feedbacks of enhanced and reduced water pressure, depth and flow velocity that in turn causes major variations in floodplain flows and inundation patterns (Sanyal, 2017). Embankments in many countries are prone to failure.

The 1980 report by the RBA provides an integrated and scientifically based plan for flood control, including inter alia an evaluation of the costs and effectiveness of embankments (Chatterjee, 1988). A committee to review the RBA report was established in 2001, and in 2003 it found that flood damage assessment does not follow the RBA's recommendations (along with most of the other 207 recommendations), there is a lack of post-project performance of past flood management works, unplanned incursions onto floodplains has reached alarming proportions, and insufficient attention has been paid to inter-state and international issues relating to floods (National Disaster Management Authority, 2008). The unplanned incursions onto floodplains may be a manifestation of the levee effect, referred to earlier. The levee effect occurs as people become complacent about flood hazards because of construction of levees (embankments or dykes). Because they feel safe, they settle in locations that may be subject to very large floods despite the embankments.

As already seen, embankments are the dominant FPS in India since Independence (Mohapatra and Singh, 2003). The reports referred to above include many concerns about the effectiveness of embankments, and the time series of deaths and economic damage from the CWC contain additional insights. Embankment construction in India began in earnest after the devastating flood of 1954 that affected much of northern India. It might therefore be expected that economic data normalized for the growing wealth of the country will show a steady decline as the FPS becomes effective, and normalized deaths should also decrease.

Normalised economic damage increased from 1953 to 2011 (Mann-Kendall Tau b, $\mathrm{p}=0.0000001$ ) and showed no trend between 1982 and 2011. As already noted this simple trend analysis is insufficient to capture the dynamics of damages (Fig. 1). The cause(s) of the variations seen in Fig. 1 are not clear, but the rise to 1985 occurs as embankment construction increased suggesting some role for the levee effect. The reduction to about 1995 may have been a result of the increased effectiveness of longer stretches of embankments, but the increase in damage thereafter suggests that the levee effect once more is important. While the available evidence is meagre, it is also possible that the increase since 1995 is a result of almost complete cessation of embankment construction and the increasing problem of embankment maintenance and frequent breaches (ICIMOD, 2013; Thakkar, 2006; Gupta et al., 2003). Normalized deaths increased from 1953 to 1981 $(p<0.01)$, as embankments were being constructed, and then declined to $2011 \quad(\mathrm{p}<0.01)$ when embankments were more extensive. But during the period when normalized deaths were falling, so too was the area affected by floods $(p<0.01)$. It is therefore not clear if reduced flood area or increased embankment length, or some other factor, has caused the reduced death rate.

Another process that has been occurring in parallel with embankment construction and other forms of FPS is encroachment by settlements onto flood-prone land. There does not appear to be an Indiawide survey-based account of the extent and nature of this process but changes in satellite-based measurements of nightlights along rivers provides a proxy for encroachment and is highly correlated with flood-related economic damage (Ceola et al., 2014). Between 1992 and 2012 the average annual nightlight increase along rivers in India was 2.07\% compared with $0.47 \%$ in Pakistan, $0.12 \%$ in Bangladesh, an astonishing $17.58 \%$ in Bhutan and 5.55\% in China. 
The increase of economic damage in India between 1992 and 2010 (not 2012 as used by Ceola et al., 2014 ) is $35 \%$ per annum according to the CWC, and the nightlight data exposure has increased by $2.07 \%$ per annum producing economic damage per unit area in 1992 of $110 \pm 30 \mathrm{USD} \mathrm{km}^{-2}$ and by 2012 USD $166 \pm 50 \mathrm{~km}^{-1}$, an increase of $51 \pm 30 \%$. Given that the uncertainties, attached to the calculated increase of economic damage based on the relationship between nightlight observations and damage, are large and encompass the estimate from the CWC (for which there are no estimates of uncertainty), the most parsimonious conclusion is that the two estimates are identical.

Another approach to the assessment of the effectiveness of embankments is to employ a comprehensive benefit : cost analysis that includes dis-benefits. Kull et al. (2008) assembled as much data as possible for the Rohini River catchment in Uttar Pradesh, while recognizing the limitations of what they had been able to do. Their analysis shows that when viewed from a social welfare or 'peoplecentred' perspective, in which all costs and benefits are included, past investments in embankments have a benefit : cost ratio of 1 and are therefore not economically beneficial. Climate change is likely to reduce the benefits even more so that the benefit:cost ratio will be $<1$. However, they also conclude that the embankments represent a sunk cost and there will be economic benefit (benefit : cost of about 2) from their proper maintenance under both current and future climate. A similar but qualitative study by Dixit et al. (2008) in the Lower Bagmati River catchment in Bihar shows that the costs of current structural approaches have exceeded their benefits. They suggest that nonstructural measures, such as better early warning systems, raising the plinths below houses, and providing boats have fewer costs than benefits, but they may not be sufficient as climate changes. Kull et al. (2008) suggest that a basket of non-structural measures has a benefit: cost ratio of 2 to 2.5 and is resilient under a changed climate. The measures include: raising of house plinths, fodder stores, hand pumps and toilets; rainwater harvesting; early warning systems; village food shelters including grain and seed banks; maintenance of key drainage bottlenecks; development of self-help groups; provision of community boats; promotion of flood-adapted agriculture; and strengthening of the health care system.

Kunreuther and Michel-Kerjan (2012) have employed a preliminary and simplified benefit : cost analysis for various flood mitigation measures in more than 30 countries, focusing on residences and schools. They conclude that raised house plinths, low walls around houses, and early warning systems all have high and positive benefit : cost ratios. But they make no reference to the criticisms of embankments, which are large versions of walls around houses; although low walls could possibly be built better than many tall embankments.

From the different approaches to the assessment of the effectiveness of structural flood protection, which mostly consists of embankments, it is clear they have not conferred the promised protection (Gupta et al., 2003), and in many places have caused problems that make them economically inadvisable. But many people now living near embankments have not known a landscape without them and so they have become dependent upon them for safety and also for refuge during the largest floods. Some critics have called for the removal of embankments but this is unlikely after such a bad flood season, and because they confer some measure of protection. It is much more likely that embankments will remain and other non-structural DRR measures put in place to complement them. By introducing non-structural measures while maintaining structural measures it may be eventually possible to move from 'flood control' to a greater emphasis on 'living with floods'.

To provide input to the planning of what is hoped will be the next phase of flood DRR in India, a workshop of social scientists, policy scientists, geoscientists, climatologists, hydrologists, civil engineers, policy makers and administrators from about 20 institutions and national agencies was co-sponsored by the Indian National Science Academy (INSA) and the Institute of Water Policy at the National University of Singapore, and held at INSA during February 1012, 2017.

\section{The Workshop}

The workshop deliberated on the key issues in flood DRR, including: hydrology, river changes, and histories of floods; the relations between floods and the monsoon and future climate; human vulnerability and 
resilience; data measurement, data fidelity, data archiving, data accessibility, and data mining; integrated flood mitigation including estimation of future human and infrastructure vulnerability; current governance structures and integration of continuous learning in policy formulation; aspects of institutional memory; and land use regulation and zoning. Ways to achieve an integrated and synergistic understanding of these issues were considered so that Future India has disaster management plans with proactive DRR governance based on an understanding of the entire system. When implemented it is expected that risk will be reduced and resilience maximized.

\section{Recommendations}

The following recommendations from the workshop consist of a long list without priorities thereby causing a problem for policy makers who need to know where to place their emphasis (see Cairney, 2016 for a discussion of this problem). It is hoped that the list will be used in discussions with policy makers so that priorities for action can be jointly identified. Also many organizations in India have made recommendations for flood mitigation, but no attempt is made to relate their recommendations to those included here because this would require another paper of similar length to this one given that many recommendations have been made from soon after Indian Independence. That said, the people at the workshop had deep knowledge of the recommendations that had been made previously and so the list that follows contains much of what has come before.

\section{New Knowledge, Data Synergy and Modeling}

1. The flood hazard needs to be assessed catchment by catchment across India, including the use of existing analyses of flood frequency and magnitudes augmented where available by longer geological and historical records. This should also include assessment of the perceptions by local people of the flood risk.

2. Forecasts of the effects of climate change on precipitation are available, but these need to be applied to the anticipation of extreme floods, taking into account the non-linear relationship between precipitation and flood flows, again catchment by catchment. This may need development of regional precipitation scenarios based on regional climate models and establishment of a clear understanding of the meteorological condition that results in floods and the role of other local factors. Further, sediment budgeting to determine channel infilling and therefore loss of flood conveyance capacity in the context of future scenarios of climate change needs to be included in flood studies. This will also call for studies of ground water including withdrawal, documentation of baseline flows and modelling of the impact of such processes under accelerated withdrawal and extreme rainfall events. The role of early rain that causes snow-melt and therefore adds to flood risks needs to be quantified.

3. Identification of areas that may become prone to flooding under scenarios of increasing extreme events and development requires regionally and locally specific disaster management systems. This will require new knowledge generation with a synergistic use of modelling efforts and understanding of local hydrological conditions.

4. The relationships between flood types, river types and dynamics, land use, climate, sediment transport and channel sedimentation, and embankments need to be more extensively investigated in flood-prone areas of the country. Catchment and reach scale relationships between structural measures and socioeconomic damage data need to be developed to better assess the effectiveness and impact of flood management structural measures.

5. Identification of vulnerable coastal areas that are prone to non-monsoon flooding due to tidal effects under anticipated sea level rise.

6. Understand the catchment characteristics (of each village or settlement) and set up of institutional responsibility for managing the runoff within these catchments. Dealing with the excess runoff at the catchment level will ensure reduction in flash floods. Efforts of catchment treatment with forestation and soil rehabilitation can help to retard runoff velocity. A detailed atlas for each river catchment should provide a way ahead. 
7. Simulate the results of the failure of proposed dams both individually and cumulatively, assuming multiple failures. The simulations should include failures caused by great earthquakes and large floods, with attention to downstream impacts, various levels and timing of warnings, and levels of preparedness by local communities.

\section{New Technologies and Data}

1. For real time flood forecasting, current efforts should be accelerated and augmented by recent developments in remote sensing and remotely operated sensor networks for the measurement of flood discharges.

2. Remote sensing data needs to be more effectively used as a basic historical data source. Multi-year remote sensing data could be used in ungauged river basins to identify and map the frequently flood-affected areas.

3. Current efforts to use technology for warnings should be accelerated. Once again development of intelligent sensors and their deployment will be needed.

4. Floods in the Himalaya are often a result of a combination of precipitation and landslide lake outburst floods, requiring mapping of this multihazard of landslides and floods. And more attention should be paid to anticipation, real time monitoring, and mitigation of glacial lake outburst floods aided by land use zoning studies. Flood wave propagation models, including sediment transport, need to be developed for various channels and for different scenarios of Lake Outbursts floods. Extensive use of remote sensing capabilities is anticipated.

\section{Governance Paradigms}

1. There is a clear need to identify the geomorphic and hydrologic space needed by a river to function. And this should be an integral part of a complete assessment of the costs and benefits of reservoirs and embankments as flood mitigation measures, along with assessment of non-structural measures such as floodplain zoning for a range of flood intensities, enforcement of building codes, and flexible arrangements for people to move between plots of land in different seasons. This will also require the resolution of existing tenure uncertainties and the development of more flexible land tenure arrangements, particularly along rivers that are subject to significant riverbank erosion.

2. A balance is required between the current paradigm of 'controlling floods' and the internationally evolving paradigm of 'living with floods'. Integration of traditional wisdom in the planning process so as to provide cost effective measures for flood resilience measures will be of considerable significance.

3. Data accessibility, archiving, fidelity, and analysis should receive more attention, bureaucratic blockages to data sharing removed where possible, and a data sharing platform created for wider use.

4. More effort on data sharing, mutual learning, and science based resolution of trans-boundary issues to alleviate flooding and improve community resilience in downstream riparian states. This effort must of course also include China.

5. While interlinking of rivers is a possible engineering solution in partially reducing floods on short time scales, the implications in terms of long term changes on ecological regimes and their effects, needs careful scientific scrutiny.

6. Human vulnerability to floods must become a critical issue for disaster mitigation because currently most emphasis is only on understanding, monitoring, and anticipating the hazard of floods. Without reduction of human vulnerability there will be no reduction of risks and therefore no reduction in loss of life and economic damage.

7. Empowerment and resourcing of local communities for disaster risk reduction should be developed as a matter of urgency, with minimal blockages from higher levels in the governance hierarchy. Also a mechanism is required to retain institutional memories of floods, document failures and successes of flood mitigation measures, and continually remind the public of events in the past and lessons therefrom. Creating of flood memorials may be 
considered as a long term reminder of impending hazards.

8. Akin to environmental impact assessment, disaster risk reduction assessment should be included in all master plans for the smart cities, and for all new developments nation-wide to complement the current requirements that exist only for government funded projects. Urban floods due to intense use of water and sewage generation and disposal have received insufficient attention so far and, given the growth of large townships, needs a proactive assessment.

9. Effort is required to build understanding among all levels of Indian society about the ways in which flood disasters can evolve slowly and that heavy precipitation is not the only cause.This will require the use of conceptual frameworks that include key components and feedbacks between these components that sometimes defeat the purpose of a policy intervention. This understanding needs to be developed in different ways for different parts of society, and in particularly flood prone areas should include the involvement in the analysis of a wide crosssection of society. Such a process would assist any moves to greater empowerment of local communities which are critical to the success of any flood disaster and risk mitigation effort.

10. Setting up a Drainage Committee at the settlement level comprising various institutions working on flooding/drainage along with citizens will help in removing the redundancy and multiplicity of efforts. Efforts need to be taken to coordinate various departments working in this direction; e.g., Water Resources

\section{References}

AGFA, (2017) http://www.wri.org/resources/maps/aqueductglobal-flood-analyzer; accessed 19/6/17)

Cairney P (2016) The Politics of Evidence-Based Policy Making. pp 137 Palgrave MacMillan

Census of India (2011) http://censusindia.gov.in/2011-provresults/paper2/data_files/india/Rural_Urban_2011.pdf; accessed 10/10/17).
Department, Public Works Department (roads), local authorities (municipal bodies, district bodies, etc.), Town and Country Planning departments, and the Central Water Commission.

11. Development of a synergistic governance structure and reduction of interfaces and time delays between government agencies is urgently needed. Presently too many institutions participate and the speed of implementation of any policy is determined by the slowest participant.

12. A dedicated centre for flood risk analysis at NIDM, or at an academic institution, merits consideration.

\section{Acknowledgements}

The following participants at the workshop provided valuable input: Ranjana Chauduri (Teri University); Arun Kansal (Teri University); Snigdha Ghatak (GSI); Mohan Banerjee (Delhi University/INSA); R.B. Singh (Delhi University); Vishwas S. Kale (Pune University); Ramesh Vellore (IITM); Bindhy Wasini Pandey (Delhi University); Shashikant Chopde (ISET); Nayan Sharma (IIT Roorkee); Arun Sahdeo (UNDP); Shailesh Nayak (Ministry of Earth Sciences); Anup Karanth (World Bank); Shakeel Ahmed (NGRI); R. Baskar (University of Hissar); Masood Ahmed (NGRI); Subhash Anand (University of Delhi); Nirbhav Kumar (University of Delhi); R.N. Singh (NGRI); V.M. Tiwari (NGRI); Ch. Samurembi Chanu (NGRI). The participation of RJW was made possible by the granting of a Dr Vikram Sarabhai Chair 2017 award from INSA. The project also benefited from the financial support of a Singapore Ministry of Education Academic Research Fund Tier 2 grant entitled 'Governing Compound Disasters in Urbanising Asia’ (MOE2014-T2-1-017).

Ceola S, Laio F and Montamari A (2014) Satellite nightime lights reveal increasing human exposure to floods worldwide Geophsys Res Lett $\mathbf{4 1}$ 7184-7190

Chatterjee P K (1988) Rashtriya Barh Ayog Recommendations1980 Disaster Management-India 7 21-22

Comptroller and Auditor General of India (2017) Schemes for Flood Control and Flood Forecasting, Report No. 10 of 2017. pp 10, Ministry of Water Resources, River 
Development \& Ganga Rejuvenation (http:// www.cag.gov.in/sites/default/files/audit_report_files/ Report_No.10_of_2017_Perfor mance_audit_Union_ Government_Schemes_for_Flood_Control_and_Flood_ Forecasting_Reports_of_Ministry_of_Water_ Resources\%2C_River_Development_\%2C_River_ Development_\%26_Ganga_Rejuven.pdf)

Criss R E and Shock E L (2001) Flood enhancement through flood control Geology 29 875-878

CWC (2005) http://www.cwc.nic.in/main/downloads/ Water_Data_Complete_Book_2005.pdf

Di Baldassarre G, Castellarin A and Brath A (2009) Analysis on the effects of levee heightening on flood propagation: some thoughts on the River Po Hydrolog Sci J 54 1007-1017 doi:10.1623/hysj.54.6.1007

Dixit A, Pokhrel A, Moench M, The Risk to Resilience Study Team (2008) Costs and Benefits of Flood Mitigation in the Lower Bagmati Basin: Case of Nepal Terai and North Bihar. From Risk to Resilience Working Paper no. 6. (Eds: Moench M, Caspari M,Pokhrel A) ISET, ISET-Nepal and ProVention Consortium, Kathmandu Nepal pp 34

Flood Management Organization (2012) Climate and floods still govern California levee breaks. pp 137 Central Water Commission New Delhi

Florsheim J L and Dettinger M D (2007) Climate and floods still govern California levee breaks. Geophys Res Lett 34 L22403, doi:10.1029/2007GL031702

Gupta S, Javed A and Datt D (2003) Economics of Flood Protection in India Nat Hazard 28 199-210

ICIMOD (2013) Monsoon Floods in Nepal and India: What happened and what could have been done? (www.icimod.org/?q=10932 accessed 4 March 2018)

India Meteorological Department (2010) Climate Profile of India. Met. Monograph No. Environment Meteorology-01/2010. pp 122 Government of India, Ministry of Earth Sciences

Kapur A (2010) Vulnerable India: A Geographical Study of Disasters. Sage and Indian Institute of Advanced Study, pp 269

Kull D, Singh P, Chopde S, Wajih S and The Risk to Resilience Study Team (2008) Evaluating Costs and Benefits of Flood Reduction under Changing Climatic Conditions: Case of the Rohini River Basin, India. From Risk to Resilience Working Paper No. 4 (Eds: Moench M, Caspari E, and Pokhrel A) pp 32, ISET, ISET-Nepal and ProVention, Kathmandu, Nepal
Kunreuther H and Michel-Kerjan E (2012) Policy Options for Reducing Losses from Natural Disasters; Allocating \$75 billion. Copenhagen Consensus, pp 56

McDermott T K J, Barry F and Tol R S J (2014) Disasters and development: natural disasters, credit constraints, and economic growth Oxford Economic Papers 66 750-773

Mirza M Q (2002) Global warming and changes in the probability of occurrence of floods in Bangladesh and implications Global Environmental Change 12 127-138

Mohapatra P K and Singh R D (2003) Flood management in India Nat Hazard 28 131-143

National Disaster Management Authority (2008) National Disaster Management Guidelines. Management of Floods. Government of India, pp 135

Phukan A, Goswami R, Borah D, Nath A and Mahanta C (2012) River bank erosion and restoration in the Brahmaputra River in India The Clarion 1-7

Rakhecha P R (2002) Rainfall in India Weather 27260

Sanyal J (2017) Uncertainty in levee heights and its effect on the spatial pattern of flood hazard in a floodplain Hydrolog Sci J DOI: 10.1080/02626667.2017.1334887

Scussoloni P, Aerts J C J H, Jongman B, Bouwer L M, Winsemius H C, Moel H and de Ward P J (2016) FLOPROS: an evolving global database of flood protection standards Nat Hazard Earth Sys 16 1049-1061

Singh O and Kumar M (2013) Flood events, fatalities and damages in India 1978 to 2006 Nat Hazard 69 1815-1834

Srivastava P, Tamm A, Halpin E and Yu W (2013) A US-India example in case history use in levee safety-A multi-cultural perception of what it is, and how should be applied. International Conference on Case Histories in Geotechnical Engineering, 3 (http://scolarsmine.mst.edu/icchge/7icchge/ session01/3; accessed 21/6/17)

Thakkar H (2006) What, who, how and when of Experiencing Floods as a Disaster. pp 37 South Asia Network on Dams, Rivers and People

Tobin G A (1995) The levee love affair: a stormy relationship? Water Resources Bulletin 31 359-367

UN News Centre (2017) At least 41 million people affected in floods in India, Bangladesh and Nepal, UN says (http:// www.un.org/apps/news/story.asp?NewsID=57403\#. WcyKwNup2qD accessed $24^{\text {th }}$ September 2017)

Ward P J, Jongman B, Weiland F S, Bouwman A, van Beek R, Bierkens M F P, Ligtvoet W, Winsemius H C (2013) Assessing flood risk at the global scale: model setup, 
results, and sensitivity Environ Res Lett 8044019 pp10 Ward P S and Shively G E (2017) Disaster risk, social vulnerability, and economic development Disasters 41 324-351

Winsemius H C, Aerts J C J H, van Beek L P H, Bierkens M F P, Bouwman A, Jongman B, Kwadijk J C J, Ligtvoet W, Lucas P L, van Vuuren D P and Ward P J (2015) Global drivers of future river flood risk Nat Clim Change 6381 385
World Resources Institute (2015) World's 15 countries with the most people exposed to floods. (https://www.wri.org/blog/ 2015/03/world's-15-countries-most-people-exposed-riverfloods accessed 20/6/17) Written by Tianyi Luo, Andrew Maddocks, Charles Iceland, Philip Ward and Hessel Winsemius. 